\title{
Experimental Verification of Abrasive Mass Flow Impact on the Technological Head Acceleration Amplitude and Vibrations Frequency in the Production System With AWJ Technology
}

\author{
Štefánia Salokyová ${ }^{1 *}$, Stanislav Fabian ${ }^{2}$, Tomáš Olejár ${ }^{3}$ \\ 1,2,3 Faculty of Manufacturing Technologies of Technical University of Košice with a seat in Prešov
}

\section{KEY WORDS}

Experiment, material cutting, hydroabrasive water jet, cutting parameters, abrasive, abrasive mass flow, vibration, frequency, amplitude.

\begin{abstract}
Between the technological parameters that influence the acceleration amplitude and vibrations frequency on technological head in the production system (PS) with water jet technology belongs the abrasive mass flow. The article is focused on examination of the ukrainian garnet abrasive mass flow on technological head vibrations and their frequency spectrums during cutting material HARDOX 500. The article includes description of experiment and measurement results carried out in laboratory workplace with water jet technology.
\end{abstract}

\section{Introduction}

During the operation of manufacturing systems with hydroabrasive jet technology, arising in the production system vibrations, which affect its reliability and durability, operating costs and consequently economic efficiency and operational safety. The emergence and spread of vibrations generated by water jet technology remains actual and theoretically difficult issue, which is currently not sufficiently developed. Despite the best efforts of researchers and a good knowledge of the operation in PS with water jet technology remains unexplained facts. One of them is the abrasive mass flow technological parameter affecting the acceleration amplitude and vibrations frequency on technological head, which is the subject of experimental investigation during cutting steel HARDOX 500.

\section{Experimental Sections}

The experiments were conducted in liquid jet laboratory IF HGF VŠB TU in Ostrava. The main parameters of PS with AWJ technology: [4]

\section{- multiplicator.}

The high pressured pump PTV 19/60 on the basis of the pump Flow HSQ 5X (the pressure up to $415 \mathrm{MPa}$, the passage up to 1,9 1. $\mathrm{min}^{-1}$ )

- the working area of the vat. 
X-Y CNC table WJ1020-1Z-EKO with the accessories - technological head Paser IIITM.

The type of the nozzle 10, the length of the abrasive nozzle $76 \mathrm{~mm}$.

\section{Conditions of experiment}

Table 1 shows the factors and conditions under which the experiment was realized.

Table 1: Overview of experimental conditions

\begin{tabular}{|c|c|c|}
\hline \multirow{2}{*}{ Material factors } & divided material & steel K13 - HARDOX 500 \\
\hline & material thickness & $10 \mathrm{~mm}$ \\
\hline \multirow{2}{*}{ Technological factors } & pressure & $380 \mathrm{MPa}$ \\
\hline & cutting speed & $100 \mathrm{~mm} \cdot \mathrm{min}^{-1}$ \\
\hline \multirow{6}{*}{ Factors abrasives } & type of abrasives & Ukrainian garnet \\
\hline & abrasive grain size & MESH 80 \\
\hline & \multirow{4}{*}{ abrasive mass flow } & 100 g.min ${ }^{-1}$ \\
\hline & & 300 g. min $^{-1}$ \\
\hline & & 500 g.min - $^{-1}$ \\
\hline & & 700 g.min $\mathrm{min}^{-1}$ \\
\hline \multirow{2}{*}{ Mixing factors } & the diameter of the water nozzle & $0,25 \mathrm{~mm}$ \\
\hline & the diameter of the directing tube & $1,02 \mathrm{~mm}$ \\
\hline
\end{tabular}

All measurements were made from the same starting position $X=320 \mathrm{~mm}, Y=370 \mathrm{~mm}$.

\section{Hardware and Software for Data Processing}

Hardware: The piezoelectric accelerometer from the Brüel \& Kjær (type: 4507-B-004, parameters: IEPE, TEDS, 1-axial, $100 \mathrm{mV} / \mathrm{g}$ ) was mounted to the head so that its axis was identical to the vibrations axis in the direction of the abrasive water jet. The accelerometer was connected to the AD converter (Al $\pm 5 \mathrm{~V}$ IEPE, sampling $25 \mathrm{kSps}$ ) through which was created the data record, stored in the PC as a time record of the vibration acceleration signal.

Software: For the time signal evaluation was used SignalExpress software, which is a part of the programming and development environment of LabVIEW from National Instruments. From the time record a steady part during 10 seconds was selected and by using the Fourier transformation a frequency spectrum in the range from 0 to $10000 \mathrm{~Hz}$ was generated. By using a filter (algorithm) we received an envelope of frequency spectrum. [3]

\section{Measured and Graphically Precessed Values}

The measured values are processed in the frequency spectrum range from 0 to $10 \mathrm{kHz}$ and are presented in graphical form broken down for individual feed rates of technological head. On Figs. 1, 3, 5 and 7 are evaluated the frequency spectrums of vibration acceleration amplitudes for the used abrasive mass flows of 100, 300, 500 and 700 g. $\mathrm{min}^{-1}$. On Fig. 2, 4, 6 and 8 are shown graphically the envelopes of frequency spectrums vibration amplitudes of the technological head for the used abrasive mass flows. [4]

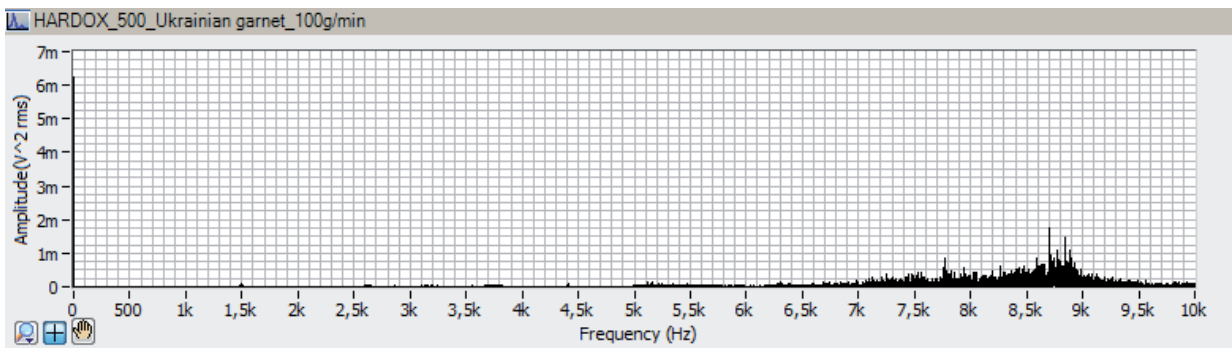

Fig. 1: The vibrations spectrum on the technological head for the mass flow $\mathrm{ma}=100 \mathrm{~g} \cdot \mathrm{min}^{-1}$ 


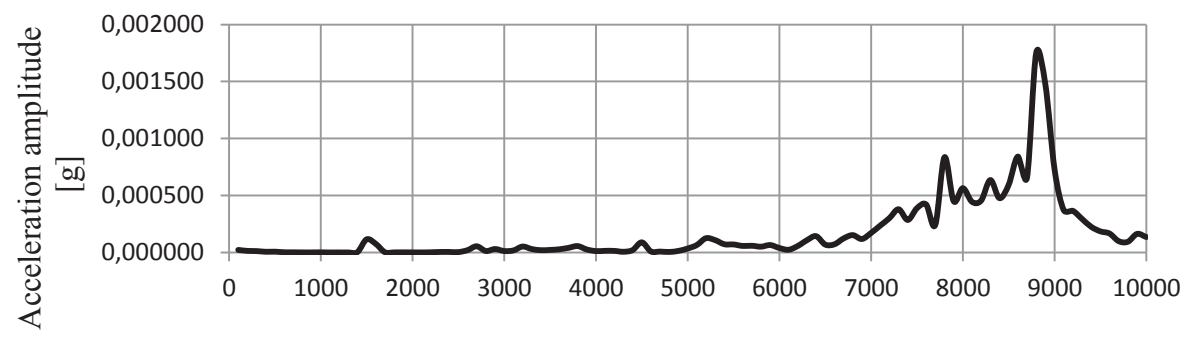

Frequency [Hz]

—abrasive mass flow $100 \mathrm{~g} / \mathrm{min}$

Fig. 2: The envelope of vibrations frequency spectrum on the water jet technological head for the mass flow $100 \mathrm{~g} \cdot \mathrm{min}^{-1}$.

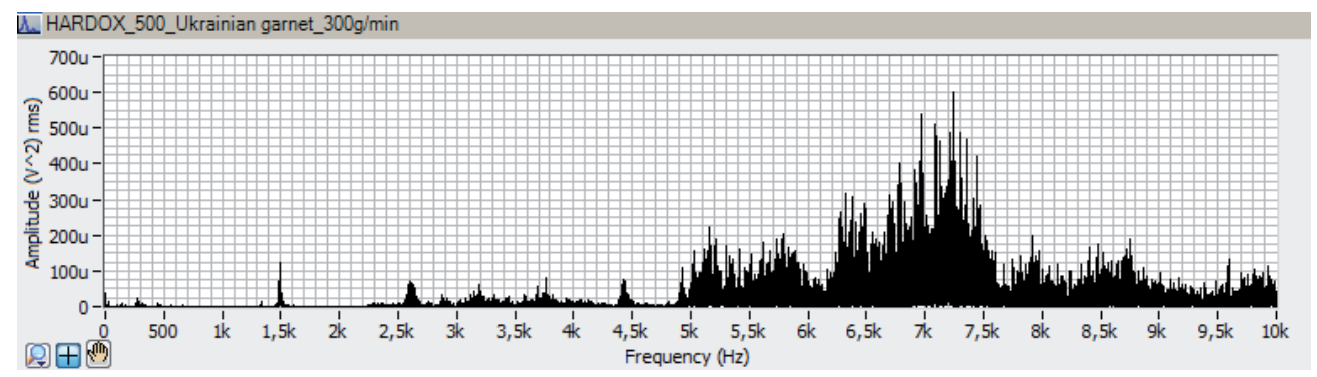

Fig. 3: The vibrations spectrum on the technological head for the mass flow ma $=300 \mathrm{~g} \cdot \mathrm{min}^{-1}$.

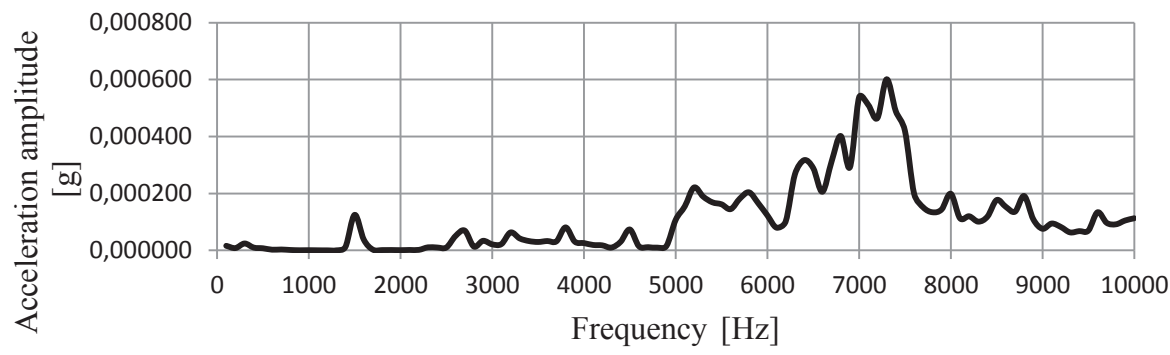

-abrasive mass flow $300 \mathrm{~g} / \mathrm{min}$

Fig. 4: The envelope of vibrations frequency spectrum on the water jet technological head for the mass flow $300 \mathrm{~g} \cdot \mathrm{min}^{-1}$.

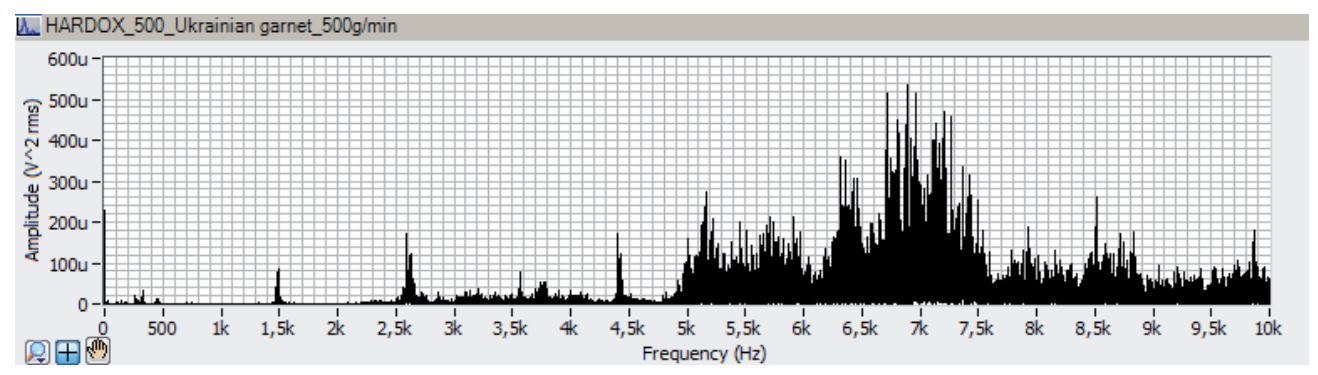

Fig. 5: The vibrations spectrum on the technological head for the mass flow $\mathrm{ma}=500 \mathrm{~g} \cdot \mathrm{min}^{-1}$ 


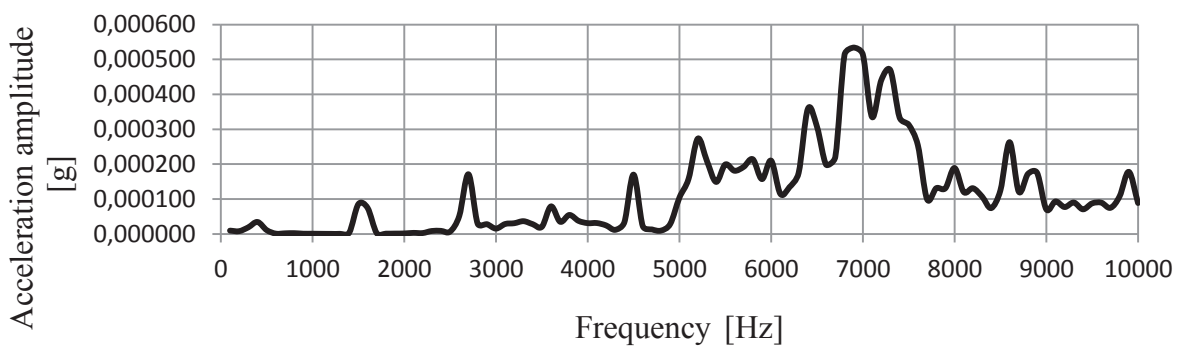

—abrasive mass flow $500 \mathrm{~g} / \mathrm{min}$

Fig. 6: The envelope of vibrations frequency spectrum on the water jet technological head for the mass flow $500 \mathrm{~g} \cdot \mathrm{min}^{-1}$.

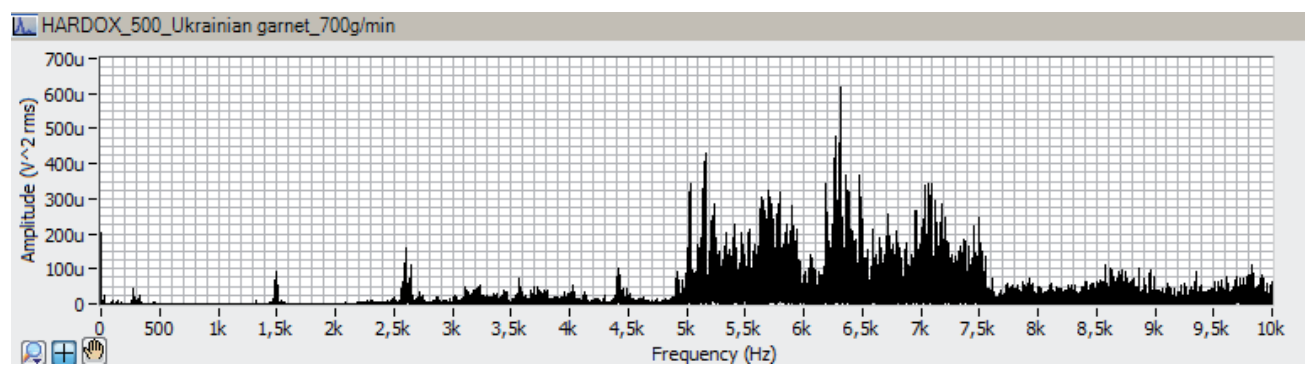

Fig. 7: The vibrations spectrum on the technological head for the mass flow ma $=700 \mathrm{~g} \cdot \mathrm{min}^{-1}$

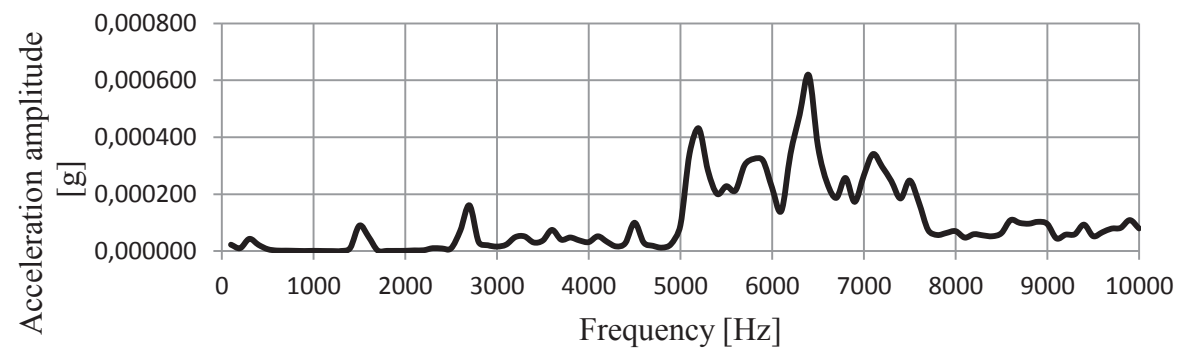

—abrasive mass flow $700 \mathrm{~g} / \mathrm{min}$

Fig. 8: The envelope of vibrations frequency spectrum on the water jet technological head for the mass flow $700 \mathrm{~g} \cdot \mathrm{min}^{-1}$

\section{New Knowledge Obtained by Evaluating of Experiments}

From the group of ukranian garnet abrasive mass flows in the experiment when dividing steel HARDOX 500 with MESH 80 grit it were found the smallest vibrations values for the abrasive mass flow 500 g. $\mathrm{min}^{-1}$ where were the maximum vibration acceleration amplitude measured of 0,534 $\mathrm{mg}$ at a frequency of $6,9 \mathrm{kHz}$. When using the mass flows of 100 g.min ${ }^{-1}, 300$ g.min ${ }^{-1}$ and 700 g.min ${ }^{-1}$ occurred during cutting one increased band of vibrations acceleration amplitude for each investigated mass flow. The increased band of mass flow $700 \mathrm{~g} \cdot \mathrm{min}^{-1}$ occurred in the frequency range from 5,0 to $7,5 \mathrm{kHz}$ where the maximum vibrations acceleration amplitude reached a value of $0,618 \mathrm{mg}$ at a frequency of $6,4 \mathrm{kHz}$. One band of vibration acceleration amplitude occurred when using mass flow 300 g.min ${ }^{-1}$ in the frequency range from 6,2 to $7,7 \mathrm{kHz}$, where was the maximum vibrations acceleration amplitude measured 0,601 mg at a frequency of 7,3 kHz. Less favorable vibrations amplitudes from the evaluated set of mass flows were measured at a flow of 100 g. $\mathrm{min}^{-1}$, where the increased band occurred in the 
frequency range from 7,0 to $9,5 \mathrm{kHz}$ with maximum vibrations acceleration amplitude of $1,751 \mathrm{mg}$ at a frequency of $8,8 \mathrm{kHz}$. In all the abrasive mass flows used during cutting in the frequency range from 5,0 to $7,5 \mathrm{kHz}$ are found approximately the same acceleration amplitude values ranging from $0,107 \mathrm{mg}$ to $0,42 \mathrm{mg}$.

\section{Conclusion}

From the experiment evaluation is clear, that the abrasive mass flow has, but in the difference scale on the formation, spread and intensity of technological head vibrations in the water jet cutting process. Based on the graphical dependencies review from the vibrations process can be said, that when cutting steel HARDOX 500 of thickness $10 \mathrm{~mm}$, feed rate $100 \mathrm{~mm} \cdot \mathrm{min}^{-1}$ and a pressure of $380 \mathrm{MPa}$ in terms of vibrations is preferable to use the abrasive mass flow of $500 \mathrm{~g}^{\mathrm{min}} \mathrm{m}^{-1}$ in comparison with the mass flows of 100 g.min ${ }^{-1}, 300$ g.min ${ }^{-1}$ a 700 g.min ${ }^{-1}$. Even when the vibrations acceleration amplitude value reached in the experiment in the worst case value $1,751 \mathrm{mg}$ at a frequency of $8,8 \mathrm{kHz}$ the value in operation for prolonged exposure although may have some negative impact on reliability, durability, operating costs, economic efficiency and operation safe of the PS with AWJ technology. However, this adverse effect does not reach significant adverse up to critical values.

\section{References}

[1] VASILKO, K., KMEC, J.: Delenie materiálu, In.: Datapress Prešov, Prešov 2003, s. 232, ISBN 80-7099-903-9

[2] KREIDL, M., ŠMÍDL, R.: Technická diagnostika - senzory, metódy, analýza signálu. In.: Ben Praha. 2006. s. 406. ISBN 80-7300-158-6

[3] FABIAN, S., KRENICKÝ T.: Vibrodiagnostika výrobných systémov s technológiou AWJ. In.: Spravodaj ATD SR, 2008, pp. $26-27$, ISSN 1337-8252

[4] SALOKYOVÁ, Š:: Návrh metód a technických systémov (hardvér a softvér) pre elimináciu vibrácií a hlučnosti s aplikáciou na výrobné systémy s vybranými druhmi technológie. Písomný materiál k dizertačnej práci. 08.04.2011. Prešov. 2011

[5] SALOKYOVÁ, Š., FABIAN, S.: The influence of abrasive mass flow on vibrations in the water jet cutting process. 2011. In.: Výrobné inžiniersvto. Roč.10, č. 1 (2011), s. 31 - 34. ISSN 1335-7972

[6] KJACKO, P., KRENICKÝ, T., SALOKYOVÁ, Š., RIMÁR, M.: Zistovanie vibrácií technologickej hlavice $v$ procese rezania vodným prúdom. 2011. In.: Strojárstvo extra.č. 5 (2011), s.
46/1-46/3. - ISSN 1335 - 2938

[7] FABIAN, S., SALOKYOVÁ, Š.: Research and analysis of a cut material sort influence on vibrations of a technological head at cutting by technology AWJ. 2010. In: Scientific Papers: operation and diagnostics of machines and production systems operational states: vol. 3. - Lüdenscheid : RAMVerlag, 2010 P. 99-103. - ISBN 978-3-942303-04-0

[8] FEDÁK, M., FABIAN, S.: An example of theoretical knowledge application in the vibrodiagnostical laboratory, In: Výrobné inžninierstvo, roč.6, no.3, 2007, p.75-78, ISSN 1335-7972

[9] BIČEJOVÁ, L. - FABIAN, S.: Influence of fineness abrasive and cutting speed change on vibrations formation at cutting using AWJ technology, Scientific Papers, 2009, s. 88 - 93. ISSN 978-3-9802659-8-0 